\title{
Line Difference in Effects of Thymectomy and Thymus Transplantation on Marek's Disease Resistance in Chickens
}

\author{
Fazlollah Afraz, Yoshio Yamamoto and Ikuo Okada \\ Faculty of Applied Biological Science, Hiroshima University, \\ Higashi-Hiroshima 724
}

\begin{abstract}
The present study was conducted to investigate genetic effects in cell-mediated immunity in resistance to Marek's disease (MD), using the method of thymectomy and thymus transplantation. Chicks from the GVHR-HA and GVHR-LA lines selected for high and low competences in graft-versus-host reaction (GVHR) were thymectomized and some of them were mutually transplanted with the other line's thymus. The chicks were inoculated with the JV strain of MD virus. MD incidence and MD mortality were compared among three groups; control, thymectomized and thymus transplanted. The HA line seemed to be more resistant to MD than the LA line. In the thymectomized groups, MD mortality increased in the HA line and decreased in the LA line. Mean days at MD incidence and MD death also showed the similar trend. In the thymus transplantation groups, significant increase in mortality was observed in the HA line which received thymus transplants from the LA line, while a non-significant increase was also observed in the LA line received the HA thymus. Similar trend was also observed on the mean days at MD death. It was suggested that MD susceptibility might be transferred by thymus grafting.
\end{abstract}

(Jpn. Poult. Sci., 28 : 300-305, 1991)

Key words: Marek's disease, cell-mediated immunity, thymectomy, thymus transplantation, genetic resistance.

\section{Introduction}

Marek's disease (MD) is a malignant, contagious disease in chickens caused by MD virus and is characterized by the development of lymphoid tumor ${ }^{1}$. Although all chickens are virtually susceptible to MD virus infection, genetic variation in resistance of chickens to MD has been amply demonstrated by several investigators ${ }^{2-4}$.

At least two forms of genetic resistance to MD are known. One is the resistance associated with certain major histocompatibility complex alleles, specifically the $B^{21}$ allele. It was found that chickens carrying the $B^{21}$ allele were more resistant to MD than those carrying the $B^{19}$ allele ${ }^{5)}$. The association of other $B$ alleles such as $B^{2}, B^{6}$, $B^{8}$, was also reported by BRILes et $a l .{ }^{6)}$ and OKADA et $a l .{ }^{4)}$. The other is the association of MD resistance with immunocompetences ${ }^{7-9}$ ). Especially, the important role of cell-mediated immunity in resistance to MD was reported by several researchers ${ }^{10-12)}$. The present experiment was designed to test genetic effects in cell-mediated immunity on MD resistance of chickens by thymectomy and thymus

Received Mar. 29, 1991 
transplantation between the GVHR-H and GVHR-L lines with different cell-mediated immunocompetences.

\section{Materials and Methods}

\section{Chickens}

The chickens were obtained from two White Leghorn lines, GVHR-H and GVHR-L, which had been established by eight generations of selection for high and low competences of splenomegaly in $\mathrm{GVHR}^{13)}$. Both lines were divided into two sublines, each subline consisting of either $B^{9} B^{9}$ or $B^{11} B^{11}$ homozygotes. In this experiment, only the $B^{11} B^{11}$ sublines (HA and LA) of the $\mathrm{H}$ and L lines were used.

Eggs were incubated in an automatic incubator. Hatched chicks were then wing-banded and used for the experiments. Chicks were kept in batteries during the whole experimental period in an isolated condition.

\section{Surgical procedures and irradiation}

Newly hatched chicks were thymectomized under ether anaesthesia. Seven pairs of thymus were completely taken off with forceps by opening about $3 \mathrm{~cm}$ of neck skin. After thymectomy, the chicks were irradiated with X-ray of $650 \mathrm{R}$.

The thymus fragments were kept in a medium which had the following composition :

$\begin{array}{lc}\text { RPMI-1640 } & 10.2 \mathrm{~g} \\ \text { Kanamycine } & 80.0 \mathrm{mg} \\ \text { Distilled water } & 1.0 \mathrm{l} \\ 7 \% \text { sodium bicarbonate } & 20.0 \mathrm{ml} \\ \text { L-glutamin } & 0.3 \mathrm{~g} \\ \text { Fetal calf serum } & 15.0 \%\end{array}$

The medium including fragments of thymus was kept in a refrigerator $\left(4^{\circ} \mathrm{C}\right)$ until use.

For the transplantation of thymus, seven pairs of thymus from donor chicks were implanted into the neck of thymectomized host chicks. The thymectomized chicks of the HA line received thymus from the LA line and vice versa.

Challenge experiment of Marek's disease virus

The JM strain of MD virus was supplied from Kanonji Institute, Research Foundation for Microbial Diseases of Osaka University. Chicks of each line were divided into three groups ; control, thymectomized and transplanted. All chicks were inoculated intramuscularly with MD virus of a quantity of $3.9 \times 10^{3} \mathrm{PFU} / 0.2 \mathrm{~m} l$ when the transplantation operations were finished. The chicks were raised together in an isolation room for 9 weeks, and MD incidence and MD mortality were checked daily. The day of MD incidence indicates the day that the chick showed characteristic MD symptoms such as paralysis, and the day of MD death means the day on which the chick fell down by severe paralysis. Autopsies were performed on each dead chick to detect MD disease signs, specifically in the nerve of the leg. The experiment was conducted in three replications. Final incidence and mortality in each group were compared with those in the appropriate control. 
The chi-square test was used to check significant difference between groups in the total MD incidence and MD mortality. Data of the day of MD incidence or MD death were analyzed by analyses of variance with the least-squares procedures ${ }^{14)}$.

\section{Results and Discussion}

The total MD incidence and MD mortality in each treated group were summarized in Table 1, and the least-squares means and the standard errors of the age in days at $\mathrm{MD}$ incidence and MD death are shown in Table 2. In the non-treated control groups, MD incidences of both $\mathrm{HA}$ and LA lines were almost the same. However, MD mortality was lower in the HA line than in the LA line. The difference was nearly significant statistically. Mean days at MD death were also later in the HA line than in the LA line. These results suggest that the HA line is more resistant to MD than the LA line. The present results are quite different from the results of AsHIKAGA et $a l .{ }^{15)}$. They reported that the LA line was more resistant in both MD incidence and MD mortality than the HA line. HARTMANN et al. ${ }^{16)}$ tested genetic resistance of lines and line crosses in two different years and two different environments, and found that the line $\times$ year and line $\times$ environment interaction effects on MD mortality were

Table 1. Total MD incidence and MD mortality in each experimental group at 9 weeks of age

\begin{tabular}{cccccc}
\hline \hline Line & Thymectomy & $\begin{array}{c}\text { Thymus transplanted } \\
\text { from }\end{array}$ & $\begin{array}{c}\text { No. of } \\
\text { Birds }\end{array}$ & $\begin{array}{c}\text { Total MD } \\
\text { incidence }(\%)\end{array}$ & $\begin{array}{c}\text { Total MD } \\
\text { mortality (\%) }\end{array}$ \\
\hline \multirow{3}{*}{ GVHR-HA } & - & - & 27 & 63.0 & 22.2 \\
& + & - & 32 & 71.9 & 37.5 \\
& + & GVHR-LA & 29 & 72.4 & $48.3^{*}$ \\
\hline \multirow{3}{*}{ GVHR-LA } & - & - & 40 & 62.5 & 45.0 \\
& + & - & 28 & 78.6 & 39.3 \\
& + & GVHR-HA & 25 & 80.0 & 68.0 \\
\hline
\end{tabular}

${ }^{*}$ The difference from the non-treated control is significant at $\mathrm{P}<0.05$ level.

Table 2. Least-squares means and standard errors of the age in days at MD incidence and MD death

\begin{tabular}{|c|c|c|c|c|c|c|}
\hline \multirow{2}{*}{ Line } & \multirow{2}{*}{ Thymectomy } & \multirow{2}{*}{$\begin{array}{c}\text { Thymus transplanted } \\
\text { from }\end{array}$} & \multicolumn{2}{|c|}{ MD incidence } & \multicolumn{2}{|c|}{ MD death } \\
\hline & & & $\begin{array}{l}\text { No. of } \\
\text { birds }^{1}\end{array}$ & Mean days & $\begin{array}{l}\text { No. of } \\
\text { birds }{ }^{1}\end{array}$ & Mean days \\
\hline \multirow{3}{*}{ GVHR-HA } & - & - & 17 & $42.14 \pm 3.10^{2)}$ & 6 & 51.8 \\
\hline & + & - & 22 & $41.70 \pm 2.64$ & 11 & $47.92 \pm 3.39$ \\
\hline & + & GVHR-LA & 20 & $37.21 \pm 2.57$ & 11 & $43.68 \pm 3.34$ \\
\hline \multirow{3}{*}{ GVHR-LA } & - & - & 24 & $39.40 \pm 1.97$ & 13 & $45.88 \pm 3.48$ \\
\hline & + & - & 19 & $39.09 \pm 2.48$ & 10 & 47. $25 \pm 4.70$ \\
\hline & + & GVHR-HA & 20 & $38.86 \pm 2.28$ & 13 & $43.07 \pm 4.20$ \\
\hline
\end{tabular}

${ }^{1)}$ Chickens which the date of MD incidence or death was not recorded were excluded from the data.

${ }^{2)}$ Mean \pm standard error. 
statistically significant. The difference between the present and AsHikaga et al.'s results might be caused by such interaction effects.

In the thymectomized groups, the total MD incidence increased in both the HA and LA lines, but the differences from the control were small and not significant. On the other hand, MD mortality increased in the HA line and decreased in the LA line. The mean days at MD death were also consistent with the data of mortality. Although the differences from the non-treated control were not significant statistically, this result was in accordance with the results of Powell et al. ${ }^{17)}$. They observed that thymectomy brought about increase in MD susceptibility in a resistant line and decrease in a susceptible line.

In the thymus transplantation groups, total MD incidence and MD mortality increased in both the HA and LA lines, and mean days at MD incidence and MD death decreased in both lines. However, significant differences from the non-treated group were observed only in the MD mortality, which received thymus fragments of the LA line.

Gallatin and Longenecker ${ }^{11)}$ and Powell et $a{ }^{17)}{ }^{17)}$ found that thymus transplantation from susceptible chickens brought about an increase in the MD susceptibility of resistant chickens, but the reverse procedure, namely transplantation from the resistant line to the susceptible line birds, did not affect the MD resistance. The present data in MD mortality are also consistent with their results. However, actual MD mortality increased in both HA and LA lines. The results suggest that the increase of MD mortality might be considerably due to the effect of transplantation operation.

Thus, although MD susceptibility seemed to be transferred by thymus grafting from the susceptible chickens, further experiments are needed to confirm this.

\section{Acknowledgments}

We are grateful to the Kanonji Institute of the Research Foundation for Microbial Diseases of Osaka University, Kanonji, for the supply of MD virus, and to Dr. T. Furukawa of National Institute of Animal Industry, Tsukuba, for statistical analyses. This work was supported in part by a Grant-in-Aid (Bio Media Program) from the Ministry of Agriculture, Forestry and Fisheries (BMP 91-IV-1-2).

\section{References}

1) Churchill, A.E. and P.M. Biggs (1967) Agents of Marek's disease in tissue culture. Nature, 215 : 528-530.

2) Cole, R.K. (1968) Studies on genetic resistance to Marek's disease. Avian Dis., 12 : 9-28.

3) Crittenden, L.B., R.L. Muhm and B.R. Burmester (1972) Genetic control of susceptibility to the avian leukosis complex. 2. Marek's disease. Poult. Sci., 51 : 261-267.

4) Okada, I., Y. Yamada, M. Akiyama, I. Nishimura and N. Kano (1977) Changes in polymorphic gene frequencies in strains of chickens selected for resistance to Marek's disease. Br. Poult. Sci., 18 : 237-246.

5) Briles, W.E., H.A. Stone and R.K. Cole (1977) Marek's disease: Effects of $B$ 
histocompatibility alloalleles in resistant and susceptible chicken lines. Science, 195 : 193-195.

6) Briles, W.E., R.W. Briles, W.H. McGibbon and H.A. Stone (1980) Identification of $B$ alloalleles associated with resistance to Marek's Disease. In: Resistance and Immunity to Marek's Disease. (Biggs, P.M., ed.) : pp. 395-416. CEC Publ., Luxembourg.

7) Pevzner, I.Y., I.Kujdych and A.W. Nordskog (1981) Immune response and disease resistance in chickens. II. Marek's disease and immune response to GAT. Poult. Sci., 60 : 927-932.

8) ОкаDA, I. and Y. ҮАмАмото (1987) Immunocompetences and Marek's disease resistance in three pairs of chicken lines selected for different immunological characters. Poult. Sci., 66 : 769-773.

9) Calnek, B.W., D.F. Adene, K.A. Schat and H. Abplanalp (1989) Immune response versus susceptibility to Marek's disease. Poult. Sci., 68 : 17-26.

10) Sharma, J.M., R.L. Witter and H.G. Purchase (1975) Absence of age-resistance in neonatally thymectomized chickens as evidence for cell-mediated immune surveillance in Marek's disease. Nature, 253 : 477-479.

11) Gallatin, W.M. and B.M. Longenecker (1979) Expression of genetic resistance to an oncogenic herpesvirus at the target cell level. Nature, $280: 587-589$.

12) Lee, L.F., P.C. Powell, M. Rennie, L.J.N. Ross and L.N. Payne (1981) Nature of genetic resistance to Marek's disease in chickens. J. Nat. Cancer Inst., 66 : 789-796.

13) Okada, I. and H. Mikami (1974) Three generations of selection for high and low donor competences of splenomegaly in chickens. Br. Poult. Sci., $15: 1-10$.

14) HaRvey, W.R. (1988) User's guide for LSMLMW PC-1 version.

15) Ashikaga, M., I. Okada, Y. Yamamoto and H. Matsuda (1984) Interaction of the GVHR-selected lines and the $B$ genotypes in the genetic resistance to Marek's disease. Jpn. Poult. Sci., 21 : 102-110.

16) Hartmann, W., D. von dem Hagen and H.-C. Löliger (1978) Marek's disease in hens from three Leghorn lines and their crosses grown under different environmental conditions. In: Resistance and Immunity to Marek's Disease. (Biggs, P.M., ed.), pp. 443-454. CEC Publ., Luxembourg.

17) Powell, P.C., L.F. Lee, B.M. Mustill and M. Rennie (1982) The mechanism of genetic resistance to Marek's disease in chickens. Int. J. Cancer, 29 : 169-174. 


\title{
鶏のマレック病抵抗性に及ぼす胸腺摘除並びに 胸腺移植の効果の系統差
}

\author{
Fazlollah AfrAz • 山本義雄・岡出育穂
}

公島大学生物生産学部 東公島市 724

鶏における胸腺摘除並びに胸腺移植がマレック病に対 する遺伝的抵抗性に及ぼす効果について研究した。供試 した鶏群は移植片対徨主反応能について高, 低一分向選 抜によって確立された GVHR-HA 及び LA 系統であ る。粰化時にそれぞれの系統の雊より胸腺を摘除し（摘 除群)，またそのうちの一部の雊については，他うの系 統の胸腺を移植した（移植群）。手術後マレック病ウイ ルスを接種し，木処理の対照群と比較した。対照群では HA 系が LA 系より抵抗性を示したが, 摘除群では
HA 系の抵抗性が低下したのに対し，LA 系の抵抗性 は逆に増大した。移植群では，両系共抵抗性の低下がみ られたが，対照群に比へ有意な低下がみられたのは HA 系のみであった。この結果は, 胸腺移植によってマレッ ク病感受性も移されることを示焌している。

（家萮会誌，28：300-305，1991） キーワード: マレック病, 細胞性负疫, 胸腺摘除, 胸腺 移植，遺伀抵抗性 